\title{
UPAYA MENINGKATKAN AKTIVITAS DAN HASIL BELAJAR MATEMATIKA PADA MATERI BANGUN RUANG MELALUI PEMBELAJARAN KOOPERATIF TIPE BERPIKIR BERPASANGAN BERBAGI PADA SISWA KELAS VI SDN ARJANGKA
}

\author{
Saprunisiwi
}

Guru SDN Arjangka Pringgarata, saprunisiwi@gmail.com

\begin{tabular}{|c|c|}
\hline INFO ARTIKEL & ABSTRAK \\
\hline Riwayat Artikel: & $\begin{array}{l}\text { Abstrak: Dilakukan penelitian tindakan kelas sebagai upaya meningkatkan aktivitas } \\
\text { dan hasil belajar matematika melalui pembelajaran kooperatif tipe berpikir }\end{array}$ \\
\hline Diterima: 04-03-2017 & berpasangan berbagi terhadap siswa kelas VI SDN Arjangka tahun pelajaran \\
\hline Disetujui: 05-04-2017 & $\begin{array}{l}\text { 2014/2015. Dengan instrumen: lembar observasi aktivitas siswa dan guru, tes hasil } \\
\text { belajar. Hasil penelitian terdapat peningkatan aktivitas dan hasil belajar yaitu pada } \\
\text { siklus I aktivitas belajar siswa } 10,3 \text { kategori cukup aktif, hasil belajar } 66 \text { dan }\end{array}$ \\
\hline Kata Kunci: & $\begin{array}{l}\text { ketuntasannya } 80 \% \text {. Pada siklus II aktivitas belajar siswa } 14,11 \text { kategori sangat aktif, } \\
\text { dan hasil belajar siswa } 75 \text { ketuntasannya } 90 \% \text {. Disimpulkan bahwa penggunaan }\end{array}$ \\
\hline $\begin{array}{l}\text { Berpikir Berpasangan } \\
\text { Berbagi, }\end{array}$ & $\begin{array}{l}\text { metode berpikir berpasangan berbagi terhadap kelas VI SDN Arjangka meningkatkan } \\
\text { aktivitas dan hasil belajar siswa. }\end{array}$ \\
\hline
\end{tabular}

Aktivitas Belajar,

Hasil Belajar.

\begin{abstract}
Conducted classroom action research as an effort to increase the activity and learning outcomes of mathematics through cooperative learning type of thinking pairing to students of class VI SDN Arjangka lesson year 2014/2015. By instrument: observation sheet of student and teacher activity, test of learning result. Result of research there are increasing of activity and result of learning that is on cycle I student activity 10,3 category active enough, result learn 66 and mask $80 \%$. In the second cycle of student learning activities 14,11 categories are very active, and student learning outcomes 75 mask $90 \%$. It was concluded that the use of pairs of thinking method of sharing toward the class VI SDN Arjangka increase student activity and learning outcomes.
\end{abstract}

\section{A. LATAR BELAKANG}

Pembelajaran pada hakikatnya merupakan suatu proses interaksi baik secara langsung maupun tidak langsung. Secara langsung dengan melalui tatap muka dan secara tidak langsung yaitu dengan menggunakan berbagai media. Guru yang mengajar, merupakan penyebab utama bagi terjadinya proses belajar siswa meskipun tidak setiap perbuatan belajar siswa merupakan akibat guru mengajar. Walaupun demikian Guru mempunyai peran yang utama dalam melaksanakan dan menyajikan sebuah program pembelajaran yang efektif dan efisien. Proses pembelajaran yang efektif dan efisien dapat terlaksana jika persiapan guru matang dan terprogram dengan maksimal. Dengan pembelajaran yang efektif dan efisien diharapkan dapat meningkatkan hasil belajar siswa menjadi lebih baik.

Perkembangan zaman menuntut kualitas sumber daya manusia ke arah yang lebih maju sesuai dan seiring dengan kemajuan teknologi. Untuk menguasai teknologi salah satu mata pelajaran yang harus banyak dikuasai siswa adalah mata pelajaran Matematika. Berdasarkan hal tersebut pembelajaran matematika di SMP nampak permasalahan yang sering muncul dan harus segera diantisipasi, yaitu: kurangkanya motivasi belajar siswa yang disebabkan oleh faktor internal maupun faktor eksternal. Kurangnya motivasi dari faktor internal yaitu tidak adanya gairah dalam belajarnya, karena siswa kurang memahami dari tujuan untuk kebutuhan dalam kehidupannya sehingga dapat menimbulkan lemahnya minat untuk belajar. Dari faktor eksternal yaitu kurangnya perhatian dari berbagai pihak, baik pihak keluarga, maupun masyarakat. Karena dalam pendidikan yang apabila tidak didukung oleh sumber daya belajar maka pendidikan tidak akan bisa terlaksana dengan baik, sebagaimana undang-undang Nomor 2 Tahun 1989 pada pasal 35 menyatakan: "Pelaksanaan pendidikan tidak mungkin terselenggara dengan baik bilamana para tenaga kependidikan maupun para peserta didik dalam kegiatan belajar mengajar tidak di dukung sumber daya belajar yang di perlukan".

Tugas seorang guru bukan hanya sekedar mengajar melainkan bagaimana menciptakan suasana yang kondusif yang dilakukan dengan berbagai cara. Pembelajaran tidak akan sukses dengan hanya menggunakan satu cara atau pola tertentu yang dilakukan secara terus menerus. Jika seorang guru mengajar dengan satu pola tertentu pada tiap sub pokok bahasan, maka tidak akan mendapatkan hasil yang memuaskan, tetapi apabila seorang guru mengemas pola pembelajarannya dengan berbagai cara supaya pembelajarannya menarik, maka hasilnya akan memuaskan serta tahan lama.

Dengan pernyataan di atas, peneliti berupaya untuk meningkatkan pembelajaran Matematika dengan 
menggunakan pembelajaran kooperatif tipe berpikir berpasangan berbagi yang menekankan pada siswa untuk dapat berperan aktif dalam proses pembelajaran, sehingga dapat meningkatkan hasil belajar peserta didk pada mata pelajaran matematika. Dari permasalahan yang ada di SDN Arjangka, peneliti dengan adanya kesempatan, kesediaan waktu, serta biaya, maka akan mencoba untuk memecahkan permasalahan tersebut di atas dengan melakukan penelitian yang mengacu pada Penelitian Tindakan Kelas (PTK).

\section{B. METODE PENELITIAN}

\section{Jenis Penelitian}

Jenis penelitian ini adalah Penelitian Tindakan Kelas. Penelitian tindakan kelas adalah penelitian yang dilakukan oleh guru di dalam kelasnya sendiri melalui refleksi diri dengan tujuan untuk memperbaiki kinerjanya sebagai guru, sehingga hasil belajar siswa menjadi meningkat (Corebima, 2009:3).

\section{Pendekatan Penelitian}

Pendekatan yang digunakan dalam penelitian ini adalah pendekatan kuantitatif, yang termasuk data kuantitatif adalah data yang diperoleh dari aktivitas dan hasil belajar siswa.

\section{Subyek dan Obyek Penelitian}

Subyek penelitian ini adalah siswa kelas VI SDN Arjangka tahun pelajaran 2014/2015 yang terdiri dari 24 siswa dengan komposisi 11 siswa laki-laki dan 13 siswi perempuan. Sedangkan obyek penelitian ini adalah: 1) aktivitas belajar, 2) hasil belajar terhadap pembelajaran kooperatif tipe berpikir berpasangan berbagi.

\section{Rancangan Penelitian}

Prosedur yang digunakan dalam penelitian ini adalah prosedur penelitian tindakan kelas. Penelitian tindakan kelas secara garis besar terdapat empat tahapan yang lazim dilalui, yaitu: (1) perencanaan, (2) pelaksanaan tindakan, (3) pengamatan (observasi), dan (4) refleksi, yang merupakan langkah berurutan dalam satu siklus yang berhubungan dengan siklus berikutnya.

1. Tahap Perencanaan

Kegiatan yang dilakukan pada tahap perencanaan adalah sebagai berikut:

a. Membuat rencana pelaksanaan pembelajaran.

b. Menyiapkan LKS dan soal-soal diskusi kelompok.

c. Menyiapkan lembar observasi aktivitas siswa dan guru.

d. Menyusun kisi-kisi soal evaluasi.

e. Menyusun tes hasil belajar dalam bentuk pilihan ganda.

2. Pelaksanaan Tindakan

Kegiatan yang dilakukan pada tahap ini adalah melaksanakan skenario pembelajaran yang telah direncanakan. Tahap-tahap pelaksanaan tindakan ini adalah:

a. Pendahuluan
1) Mensosialisasikan pada siswa mengenai pembelajaran kooperatif tipe berpikir berpasangan berbagi.

2) Menyampaikan indikator hasil belajar.

3) Mengorganisasikan kepada siswa agar membentuk kelompok.

4) Guru memberikan motivasi dan apersepsi yang berkaitan dengan materi yang akan dipelajari.

b. Pengembangan

1) Guru membagikan LKS dan bahan percobaan yang akan didiskusikan kepada masing-masing kelompok, sambil memberi penekanan bahwa mereka akan menyampaikan atau melaporkan hasil diskusinya.

2) Guru memberi kesempatan kepada siswa untuk mengerjakan LKS dengan anggota kelompoknya setelah diberikan kesempatan untuk memikirkan sendiri.

3) Guru membimbing dan mengarahkan siswa dalam menyelesaikan LKS selama jalannya diskusi.

4) Guru memberi kesempatan tiap-tiap kelompok untuk menyampaikan hasil kerja kelompoknya.

5) Guru memberikan kesempatan kepada siswa untuk memberi tanggapan terhadap hasil diskusi.

c. Penerapan

1) Guru meminta siswa secara individual untuk mengerjakan soal latihan yang berkaitan dengan hasil diskusinya.

2) Guru menunjuk beberapa siswa untuk menuliskan jawaban dari soal di papan tulis sebagai perwakilan dari kelompoknya.

3) Guru menilai jawaban siswa serta menyampaikan langkah-langkah penyelesaian yang benar apabila terdapat kesalahan dari jawaban siswa.

d. Penutup

1) Menyampaikan kesimpulan mengenai materi yang telah dipelajari.

2) Menginformasikan materi yang akan dipelajari pada pertemuan selanjutnya dan bahan yang harus disiapkan untuk kegiatan berikutnya.

3. Tahap Observasi dan Evaluasi

Pada tahap ini dilakukan observasi terhadap pelaksanaan tindakan dengan menggunakan lembar observasi, dimana guru dan siswa di observasi tentang pelaksanaan kegiatan belajar mengajar serta aktivitas siswa dalam belajar, apakah pembelajaran kooperatif tipe berpikir berpasangan berbagi sudah dilaksanakan dengan optimal. Tahap evaluasi dilakukan setelah akhir tiap siklus dengan memberikan tes berbentuk pilihan ganda.

4. Tahap Refleksi

Hasil yang diperoleh pada tahap observasi dan evaluasi dikumpulkan dan dianalisa pada tahap ini. Dari hasil observasi dan evaluasi pada 
siklus I guru mengidentifikasi kesalahan dan kekurangan, menganalisis penyebab kekurangan dan merefleksi diri untuk melakukan persiapan menyusun tindakan perbaikan untuk melaksananakan siklus II. Tindakan yang sama juga dilakukan untuk siklus II-III dan selanjutnya.

\section{Teknik Pengambilan Data}

1. Sumber data

Sumber data dalam penelitian ini adalah siswa kelas IX_1

2. Jenis-jenis data

a. Data hasil belajar

b. Data hasil observasi aktivitas siswa

c. Data hasil observasi aktivitas guru

d. Data skenario pembelajaran

3. Cara pengambilan data

a. Data hasil belajar yang diperoleh dari hasil evaluasi dengan menggunakan tes pilihan ganda yang telah disiapkan pada akhir siklus.

b. Data tentang aktivitas siswa di dalam kelas diambil dengan menggunakan lembar observasi pada tiap siswa.

Indikator perilaku siswa yang diamati pada penelitian ini adalah:

1) Kesiapan siswa dalam menerima pelajaran.

2) Antusiasme siswa dalam mengikuti pembelajaran kooperatif tipe berpikir berpasangan berbagi.

3) Interaksi siswa dengan guru.

4) Aktivitas siswa dalam kegiatan kelompok.

5) Kerjasama kelompok dalam kegiatan diskusi.

6) Kemampuan siswa dalam menyimpulkan hasil belajar.

Setiap indikator terdiri dari 3 deskriptor, dimana skor aktivitas siswa secara klasikal untuk masing-masing deskriptor, yaitu:

TABEL 1

PEDOMAN PEMBERIAN SKOR AKTIVITAS SISWA

\begin{tabular}{|c|c|}
\hline Skor & Kriteria pemberian skor \\
\hline 0 & $\mathrm{X} \leq 25 \%$ \\
\hline 1 & $25 \%<\mathrm{X} \leq 50 \%$ \\
\hline 2 & $50 \%<\mathrm{X} \leq 75 \%$ \\
\hline 3 & $\mathrm{X}>75 \%$ \\
\hline Dimana X $=\begin{array}{c}\text { banyaknya siswa yang aktif } \\
\text { melakukan aktivitas } \\
\text { sesuai deskriptor. }\end{array}$
\end{tabular}

c. Data tentang aktivitas guru di dalam kelas diambil dengan menggunakan lembar observasi pada tiap siklus. Penilaian terhadap aktivitas guru dilakukan melalui observasi langsung dimana seorang guru yang sedang mengajar diobservasi langsung oleh observer dan observer bersama-sama guru dan siswa di dalam kelas. Sedangkan data mengenai aktivitas guru diambil dengan menggunakan lembar observasi berupa lembar aktivitas.

Indikator untuk aktivitas guru adalah sebagai berikut:

1) Perencanaan dan persiapan penyelenggaraan pembelajaran.

2) Pemberian motivasi dan apersepsi kepada siswa.

3) Pengaturan kegiatan diskusi.

4) Membimbing siswa dalam kegiatan diskusi.

5) Memamerkan hasil karya siswa.

6) Membimbing siswa dalam mengerjakan latihan soal.

7) Menutup pembelajaran

Setiap indikator terdiri dari 3 deskriptor. Dimana indikator aktivitas guru ditentukan berdasarkan kriteria penilaian sebagai berikut :

TABEL 2

PEDOMAN KONVERSI AKTIVITAS GURU

\begin{tabular}{|l|l|}
\hline \multicolumn{1}{|c|}{$\begin{array}{c}\text { Deskriptor yang } \\
\text { Nampak }\end{array}$} & \multicolumn{1}{c|}{ Tingkatan } \\
\hline $\begin{array}{l}\text { Jika semua deskriptor } \\
\text { (3) yang Nampak }\end{array}$ & $\begin{array}{l}\text { BS (Baik } \\
\text { Sekali) }\end{array}$ \\
\hline $\begin{array}{l}\text { Jika ada 2 deskriptor } \\
\text { yang Nampak }\end{array}$ & B (Baik) \\
\hline $\begin{array}{l}\text { Jika ada 1 deskriptor } \\
\text { yang Nampak }\end{array}$ & C (Cukup) \\
\hline $\begin{array}{l}\text { Jika tidak ada } \\
\text { deskriptor yang } \\
\text { Nampak }\end{array}$ & K (Kurang) \\
\hline
\end{tabular}

\section{Teknik Analisis Data}

1. Data Hasil Belajar

Data tentang hasil belajar siswa dianalisis secara deskriptif kualitatif. Sedangkan kualifikasi prestasi belajar siswa diperoleh dengan pedoman konversi seperti tabel 3 berikut:

TABEL 3

PEDOMAN KONVERSI SKOR HASIL BELAJAR SISWA

\begin{tabular}{|c|c|c|}
\hline NO. & SKOR & KATEGORI \\
\hline 1. & $85-100$ & Sangat Baik \\
\hline 2. & $70-84$ & Baik \\
\hline 3. & $55-69$ & Cukup \\
\hline 4. & $40-54$ & Kurang \\
\hline 5. & $0-39$ & Sangat Kurang \\
\hline
\end{tabular}

Untuk mengetahui adanya peningkatan hasil belajar siswa pada pembelajaran matematika yang dicapai pada tiap siklus, digunakan rumus sebagai berikut:

a. Menentukan rata-rata

$\overline{\boldsymbol{X}}=\frac{\text { Jumlah Nilai Siswa }}{\text { Jumlah Siswa Yang Mengikuti Tes }}$

(Sujdana, 1987:125)

b. Menentukan ketuntasan individual

Setiap siswa dalam proses belajar mengajar dikatakan tuntas secara individu terhadap materi pelajaran yang disajikan 
apabila siswa mampu memperoleh nilai $\geq$ KKM.

c. Menghitung ketuntasan klasikal

$$
K K=\frac{X}{N} x 100 \%
$$

Dengan KK menyatakan ketuntasan klasikal, X menyatakan jumlah siswa yang memperoleh nilai $\geq \mathrm{KKM}$, dan $\mathrm{N}$ menyatakan jumlah siswa sesuai dengan petunjuk teknik penilaian. Kelas dikatakan tuntas secara klasikal terhadap materi pelajaran yang disajikan jika ketuntasan klasikal mencapai $85 \%$.

\section{Aktivitas Siswa}

Aktivitas siswa dapat diketahui melalui observasi terhadap perilaku siswa selama mengikuti pembelajaran dengan lembar observasi terdiri dari 6 indikator, tiap indikator terdiri dari 3 deskriptor. Data aktivitas siswa dianalisis dengan cara berikut:

a. Menentukan skor untuk tiap deskriptor aktivitas siswa seperti terlihat pada table 3.1.

b. Menentukan rata-rata skor tiap indikator dilakukan dengan cara menjumlahkan semua skor pada tiap deskriptor dari indikator tersebut kemudian dibagi dengan banyaknya deskriptor pada indikator tersebut.

c. Data aktivitas siswa dianalisis secara deskriptif kualitatif dengan menggunakan skor skala 1-5, sehingga diperoleh skor maksimal ideal (SMI) adalah skor maksimalnya 3 dikalikan dengan jumlah item aktivitas siswa yang dinilai.

Kualifikasi belajar siswa ditentukan berdasarkan pedoman konversi seperti pada tabel 4 berikut:

TABEL 4

PEDOMAN KONVERSI PENILAIAN SKALA 1-5 AKTIVITAS BELAJAR SISWA.

\begin{tabular}{|c|c|}
\hline SKOR & KUALIFIKASI \\
\hline $\mathrm{MI}+1,5 \mathrm{SDI} \leq \bar{X}$ & Sangat Aktif \\
\hline $\mathrm{MI}+0,5 \mathrm{SDI} \leq \bar{X}<\mathrm{MI}+$ & Aktif \\
$1,5 \mathrm{SDI}$ & \\
\hline $\mathrm{MI}-0,5 \mathrm{SDI} \leq \bar{X}<\mathrm{MI}+$ & Cukup Aktif \\
$0,5 \mathrm{SDI}$ & \\
\hline $\mathrm{MI}-1,5 \mathrm{SDI} \leq \bar{X}<\mathrm{MI}-$ & Kurang Aktif \\
$0,5 \mathrm{SDI}$ & \\
\hline$<\mathrm{MI}-1,5 \mathrm{SDI}$ & Sangat Kurang \\
& Aktif \\
\hline
\end{tabular}

(Arifin, 2009:237)

$\mathrm{MI}=\frac{1}{2}$ (skor tertinggi ideal + skor terendah ideal)

$$
\mathrm{SD}=\frac{1}{3} \mathrm{xMI}
$$

Skor rata-rata aktivitas siswa $(\bar{X})$ dapat dihitung dengan menggunakan rumus:

$$
\bar{X}=\frac{\sum X}{N}
$$

Keterangan:

$\bar{X} \quad=$ skor rata-rata aktivitas siswa

$\sum X=$ Jumlah seluruh skor

$\mathrm{N}$ = Banyak descriptor
3. Aktivitas guru

Data tentang aktivitas mengajar guru dianalisis secara kualitatif. Data yang diperoleh dari hasil observasi dianalisis dengan cara mengidentifikasi kesalahan dan kekurangan dari aspek-aspek yang belum nampak kemudian menganalisis penyebab kekurangan dan merefleksi diri untuk melakukan persiapan menyusun tindakan.

\section{Indikator Keberhasilan}

Indikator keberhasilan penelitian ini adalah:

1. Aktivitas belajar siswa minimal berkategori aktif dan mengalami peningkatan skor rata-rata pada tiap siklusnya.

2. Ketuntasan belajar siswa sebesar $85 \%$ dari siswa di kelas yang memperoleh nilai sebesar $\geq 60 \%$ pada saat evaluasi.

3. Maka dari itu, penerapan pembelajaran kooperatif tipe berpikir berpasangan berbagi pada penelitian ini dikatakan berhasil apabila $85 \%$ siswa mencapai prestasi belajar $\geq 60 \%$, dan aktivitas belajar siswa berkategori aktif yaitu berada pada konversi nilai $10,5 \leq \bar{X}<13,5$.

\section{HASIL DAN PEMBAHASAN}

\section{Hasil Penilitian}

Penelitian ini dilaksanakan di SDN Arjangka dengan menggunakan pendekatan Penelitian Tindakan Kelas (PTK) dan berfokus pada penggunaan model pembelajaran kooperatif tipe berpikir berpasangan berbagi. Penelitian Tindakan Kelas ini dilakukan dalam 2 siklus.

Adapun rincian pelaksanaan penelitian dan hasilnya diuraikan sebagai berikut:

\section{Siklus I}

a. Perencanaan

Pada tahap perencanaan ini, langkah-langkah yang dilakukan oleh peneliti adalah sebagai berikut:

1) Menentukan pengajar dan observer pada pelaksanaan penelitian tindakan kelas ini. Dalam hal ini yang menjadi pengajar adalah peneliti yaitu guru bidang studi dan yang menjadi observer adalah rekan kerja.

2) Menyusun perangkat pembelajaran yang meliputi penyusunan rencana pelaksanaan pembelajaran, membentuk kelompok yang memiliki kemampuan akademik heterogen dengan anggota 4 - 5 orang, pedoman observasi aktivitas guru, pedoman observasi aktivitas siswa, menyiapkan lembar kerja siswa (LKS) sebagai bahan diskusi, dan membuat soal evaluasi siklus I lengkap dengan kunci jawaban.

b. Pelaksanaan tindakan

Kegiatan yang dilakukan pada tahap ini adalah melaksanakan pembelajaran sesuai dengan Rencana Pelaksanaan Pembelajaran (RPP) siklus I. 
Pada awal pembelajaran guru memperkenalkan diri, mensosialisasikan metode yang akan digunakan dalam pembelajaran, menyampaikan tujuan pembelajaran, dan mengabsen kehadiran siswa. Adapun langkah yang ditempuh adalah:

1) Guru melaksanakan pembelajaran dengan menjelaskan materi pelajaran.

2) Guru mengamati pemahaman konsep yang telah dikuasai siswa, melalui metode tanya jawab. Siswa diberikan kesempatan bertanya terhadap materi yang belum jelas.

3) Guru bersama-sama siswa membentuk kelompok yang beranggotakan 4 orang. Ketua kelompok dipilih sesuai kesepakatan dari masing-masing kelompok.

4) Guru membagikan siswa LKS kemudian siswa diminta mengerjakan LKS secara individu dengan batas waktu yang sudah ditentukan.

5) Setelah mengerjakannya secara individu siswa kemudian berpasangan dengan teman sebangkunya. Setelah berdiskusi dengan teman sebangku, siswa bergabung dengan kelompok dan membahas hasil kerjanya dipimpin oleh ketua kelompok.

6) Masing-masing wakil dari anggota kelompok secara bergiliran mempresentasikan di depan kelas, siswa yang lain memperhatikan dan memberi tanggapan.

Setelah diskusi berakhir, guru memberikan soal latihan yang dijawab bersama dan beberapa pertanyaan untuk mengingatkan materi yang sudah dibahas. Setelah itu guru bersama-sama dengan siswa menyimpulkan apa yang telah dipelajari.

c. Hasil observasi

1. Observasi aktivitas guru

Hasil perhitungan observasi aktivitas guru dapat dilihat pada tabel 5.

TABEL 5

HASIL PERHITUNGAN AKTIVITAS

\begin{tabular}{|c|c|c|}
\multicolumn{3}{c}{ GURU SIKLUS I } \\
\hline Pertemuan & $\begin{array}{c}\text { Skor } \\
\text { aktivitas } \\
\text { guru }\end{array}$ & Katagori \\
\hline 1 & 1,71 & Cukup \\
\hline 2 & 2 & Baik \\
\hline 3 & 2,71 & Baik \\
\hline
\end{tabular}

Dari hasil observasi terhadap kemampuan guru mengelola kelas dan kelompok diperoleh temuan sebagai berikut. a) Guru tidak memastikan kelengkapan alat belajar siswa, sehingga ketika diskusi tengah berlangsung, ada beberapa orang siswa yang meminta izin untuk mengambil kelengkapan belajar yang mereka lupakan.

b) Dalam menyampaikan materi, guru belum melibatkan siswa secara aktif.

c) Dalam menyampaikan materi, guru terlalu cepat sehingga beberapa siswa kurang memahami materi yang disampaikan oleh guru.

d) Guru belum dapat mengatur waktu untuk masing-masing item kegiatan yang harus dilakukan siswa sebagaimana yang telah disusun dalam Rencana Pelaksaaan Pembelajaran (RPP). Waktu yang dihabiskan lebih banyak dari yang telah direncanakan dalam RPP.

2. Observasi aktivitas siswa

Data mengenai hasil observasi aktivitas siswa untuk siklus I didapatkan bahwa nilai rata-rata aktivitas siswa adalah 2,60 dengan kriteria cukup aktif. Ringkasan hasil observasi aktivitas siswa dapat dilihat pada tabel 6

TABEL 6

RINGKASAN HASIL AKTIVITAS SISWA SIKLUS I

\begin{tabular}{|c|c|c|}
\hline Pertemuan & $\begin{array}{c}\text { Skor } \\
\text { aktivitas } \\
\text { siswa }\end{array}$ & Katagori \\
\hline 1 & 8,33 & $\begin{array}{c}\text { Cukup } \\
\text { aktif }\end{array}$ \\
\hline 2 & 10,67 & Aktif \\
\hline 3 & 12,00 & Aktif \\
\hline
\end{tabular}

Berdasarkan hasil observasi aktivitas siswa di atas, selama proses pembelajaran dengan tipe berpikir berpasangan berbagi secara umum dapat dikatakan sudah terlaksana dengan baik. Namun ada beberapa hal yang perlu diperbaiki pada siklus berikutnya yaitu:

a) Ada siswa yang belum memahami penjelasan guru mengenai materi yang disampaikan oleh guru.

b) Sebagian siswa belum bisa memanfaatkan kesempatan untuk berdiskusi dengan teman kelompoknya.

c) Siswa masih terlihat takut untuk bertanya.

d) Pembagian tugas untuk masingmasing siswa dalam kelompok 
masih belum jelas sehingga tugas-tugas dalam kelompok dikerjakan oleh satu-dua orang saja

e) Sebagian siswa belum bisa menyimpulkan materi yang mereka diskusikan.

f) Hanya beberapa siswa yang mengecek jawabannya atau mencatat jawaban yang benar dari soal latihan yang diberikan.

d. Hasil evaluasi

Evaluasi belajar siswa diadakan pada akhir pertemuan dengan cara memberikan tes berbentuk pilihan ganda sebanyak 10 soal yang dikerjakan dalam waktu dua jam pelajaran. Ringkasan hasil evaluasi siswa dapat dilihat pada tabel 7

TABEL 7

RINGKASAN HASIL EVALUASI SIKLUS 1

\begin{tabular}{|l|c|}
\hline $\begin{array}{l}\text { Jumlah siswa yang } \\
\text { mengikuti tes }\end{array}$ & 20 \\
\hline $\begin{array}{l}\text { Jumlah siswa yang } \\
\text { tuntas }\end{array}$ & 16 \\
\hline $\begin{array}{l}\text { Jumlah siswa yang tidak } \\
\text { tuntas }\end{array}$ & 4 \\
\hline Nilai tertinggi & 80 \\
\hline Nilai terendah nilai hasil & 66 \\
\hline $\begin{array}{l}\text { Rata-rata ketuntasan } \\
\text { belajar }\end{array}$ & $80 \%$ \\
\hline Prosentase keta \\
\hline
\end{tabular}

Dari tabel diatas dapat dilihat bahwa dari 20 siswa yang mengikuti evaluasi, terdapat 16 siswa yang tuntas dan 4 siswa tidak tuntas, sehingga ketuntasan belajar siswa pada siklus I ini mencapai $80 \%$ dengan nilai rata-rata 66 .

e. Refleksi

Dilihat dari hasil yang diperoleh dari siklus I, ternyata belum mencapai hasil yang diharapkan. Ketuntasan klasikal hanya mencapai $80 \%$ sedangkan ketuntasan yang ditetapkan adalah $85 \%$. Hasil observasi juga menunjukkan hasil yang kurang memuaskan. Untuk itu peneliti mengadakan penyempurnaan dan perbaikan terhadap kekurangankekurangan yang muncul pada siklus I. Adapun tindakan-tindakan perbaikan yang akan ditempuh adalah:

1) Dalam menyampaikan materi guru lebih melibatkan siswa secara aktif.

2) Guru meminta tiap kelompok untuk mendiskusikan terlebih dahulu tugas dari masing-masing siswa dalam kelompok agar kegiatan pembelajaran terarah dan semua siswa aktif dalam diskusi.

3) Sebelum pembelajaran selesai guru meminta siswa untuk mencatat jawaban benar yang telah didiskusikan bersama.
4) Guru lebih mengatur alokasi waktu dalam setiap kegiatan selama pembelajaran berlangsung.

\section{Siklus II}

Pelaksanaan siklus II ini pada dasarnya sama urutannya dengan pelaksanaan pada siklus I. Namun pada siklus II ini merupakan tahap penyempurnaan dari tahap siklus I. Tahap pelaksanaan penelitian siklus II sama dengan siklus I yang dimulai dari perencanaan, pelaksanaan tindakan, observasi, dan refleksi.

a. Perencanaan

Perencanaan siklus II tidak jauh beda dengan pelaksanaan siklus I. Pada tahap perencanaan ini juga dilakukan persiapan-persiapan sebagai berikut.

1) Meyiapkan kembali perangkat pembelajaran yang meliputi penyusunan rencana pelaksanaan pembelajaran, kelompok yang memiliki kemampuan akademik heterogen dengan anggota $4-5$ orang, pedoman observasi aktivitas guru, pedoman observasi aktivitas siswa, menyiapkan lebar kerja siswa (LKS) sebabagai bahan diskusi, dan membuat soal evaluasi siklus II lengkap dengan kunci jawaban.

2) Memeriksa kembali prasarana yang diperlukan siswa dalam menyelesaikan LKS dan soal evaluasi. Prasarana yang dimaksud antara lain penggaris, kertas buram, pensil dan lain sebagainya.

b. Pelaksanaan tindakan

Pelaksanaan tindakan pada siklus ini hampir sama dengan pelaksanaan tindakan pada siklus sebelumnya. Guru melaksanakan pembelajaran sesuai dengan rencana pelaksanaan pembelajaran (RPP) yaitu dengan menjelaskan materi kemudian guru membagikan LKS kepada setiap siswa. Setelah itu guru mengorganisasikan siswa dalam kelompok-kelompok yang terbentuk pada siklus I dan siswa belajar dengan langkah-langkah yang ada pada model pembelajaran kooperatif tipe berpikir berpasangan berbagi.

Selama diskusi berlangsung guru memantau kerja tiap-tiap kelompok dan membimbing siswa yang mengalami kesulitan. Setelah diskusi selesai guru bersama-sama siswa menyimpulkan materi yang telah didiskusikan dan memperbaiki hasil presentasi siswa yang belum sesuai dengan konsep yang benar.

c. Hasil observasi

1. Aktivitas guru

Data yang diperoleh dari observasi aktivitas guru dapat dilihat pada tabel 8 
TABEL 8

HASIL PERHITUNGAN AKTIVITAS GURU SIKLUS II

\begin{tabular}{|c|c|c|}
\hline Pertemuan & $\begin{array}{c}\text { Skor } \\
\text { aktivitas } \\
\text { guru }\end{array}$ & Katagori \\
\hline 1 & 2,71 & Baik \\
\hline 2 & 2,86 & $\begin{array}{c}\text { Sangat } \\
\text { baik }\end{array}$ \\
\hline 3 & 3 & $\begin{array}{c}\text { Sangat } \\
\text { baik }\end{array}$ \\
\hline
\end{tabular}

Secara umum, guru sudah berusaha untuk melaksanakan kegiatan pembelajaran sesuai dengan Rencan Pelaksanaan Pembelajaran (RPP). Pengaturan waktu dilakukan dengan baik, melakukan pemantuan dan bimbingan secara merata pada tiap kelompok, menyampaikan kesimpulan materi dan memperbaiki hasil presentasi kelompok yang tidak sesuai dengan konsep yang benar.

2. Aktivitas sisiwa

Data mengenai hasil observasi aktivitas siswa untuk siklus II dapat dilihat pada lampiran. Dari data tersebut, bahwa nilai rata-rata aktivitas siswa sebesar 2,86 dengan kriteria aktif. Ringkasan hasil observasi siswa dapat dilihat pada tabel 9

TABEL 9

RINGKASAN HASIL AKTIVITAS SISWA SIKLUS II

\begin{tabular}{|c|c|c|}
\hline Pertemuan & $\begin{array}{c}\text { Skor } \\
\text { aktivitas } \\
\text { siswa }\end{array}$ & Katagori \\
\hline 1 & 13,34 & Aktif \\
\hline 2 & 14,33 & $\begin{array}{c}\text { Sangat } \\
\text { Aktif }\end{array}$ \\
\hline 3 & 14,66 & $\begin{array}{c}\text { Sangat } \\
\text { Aktif }\end{array}$ \\
\hline
\end{tabular}

Pada tabel di atas menunjukkan bahwa kriteria keaktifan siswa sudah tercapai. Ada peningkatan skor rata-rata aktivitas siswa dari siklus I. Dari hasil observasi aktivitas siswa pada siklus II didapatkan bahwa siswa antusias dengan model pembelajaran yang diterapkan karena model pembelajaran ini melibatkan semua siswa. Siswa mempuyai tugas masingmasing dalam kelompoknya dan siswa merasa tertantang untuk mengeluarkan pendapatnya ketika berdiskusi.

d. Hasil evaluasi

Evaluasi belajar siswa diadakan pada akhir pertemuan dengan cara memberikan tes berbentuk pilihan ganda sebanyak 30 soal yang dikerjakan dalam waktu dua jam pelajaran. Hasil evaluasi siswa selengkapnya dapat dilihat pada tabel 10

TABEL 10

RINGKASAN HASIL EVALUASI SIKLUS II

\begin{tabular}{|l|c|}
\hline $\begin{array}{l}\text { Jumlah siswa yang } \\
\text { mengikuti tes }\end{array}$ & 20 \\
\hline $\begin{array}{l}\text { Jumlah siswa yang } \\
\text { tuntas }\end{array}$ & 18 \\
\hline $\begin{array}{l}\text { Jumlah siswa yang tidak } \\
\text { tuntas }\end{array}$ & 2 \\
\hline Nilai tertinggi & 90 \\
\hline Nilai terendah & 50 \\
\hline Rata-rata nilai & 75 \\
\hline Prosentase ketuntasan & $90 \%$ \\
\hline
\end{tabular}

Dari tabel diatas dapat dilihat bahwa dari 20 siswa yang mengikuti evaluasi, terdapat 18 siswa yang tuntas dan 2 siswa tidak tuntas, sehingga ketuntasan belajar siswa pada siklus II ini mencapai $90 \%$ dengan nilai rata-rata 75 .

e. Refleksi

Berdasarkan data yang diperoleh dari tes evaluasi dan observasi yang dilakukan, terjadi peningkatan dari siklus sebelumnya. Ketuntasan klasikal sudah memenuhi standar yang ditetapkan yaitu sebesar $90 \%$. Aktivitas siswa termasuk dalam kategori aktif.

\section{Pembahasan}

Pembelajaran yang dilakukan dengan pembelajaran kooperatif tipe berpikir berpasangan berbagi diharapkan dapat meningkatkan hasil belajar siswa dalam belajar matematika. Model pembelajaran ini dapat melatih siswa untuk berpikir, dan belajar bekerja sama dengan teman sebangku atau dengan pasangannya. Teknik ini memberi siswa kesempatan untuk bekerja sendiri serta bekerja dengan orang lain. Menurut Lie (2010:57), bahwa keunggulan dari teknik ini adalah optimalisasi partisipasi siswa, yaitu memberi kesempatan delapan kali lebih banyak kepada siswa untuk dikenali dan menunjukkan partisipasi mereka kepada orang lain.Pembelajaran kooperatif tipe berpikir berpasangan berbagi dapat mengembangkan kemampuan untuk memberikan pendapat atau gagasan dan dapat mengambil kesimpulan dari ide-ide yang dikemukakan oleh orang lain.

Dengan penerapan model pembelajaran kooperatif tipe berpikir berpasangan berbagi dapat memberikan kesempatan kepada siswa untuk mengungkapkan gagasan atau ide, baik dalam pasangan maupun dalam kelompoknya. Disamping itu, dalam interaksi di dalam kelas, siswa dapat menerima segala keterbatasan dan perbedaan yang ada dalam pembelajaran sehingga dapat meningkatkan motivasi dan memberi ransangan untuk berpikir yang bermanfaat bagi proses pendidikan jangka panjang. 
Kegiatan pembelajaran dilaksanakan sesuai dengan langkah-langkah pembelajaran yang tertuang dalam Rencana Pelaksanaan Pembelajaran (RPP) yang telah disusun. Kegiatan pembelajaran diawali dengan kegiatan pendahuluan yang berlangsung selama 10 menit. Pada kegiatan pendahuluan, guru mengawali pembelajaran dengan memeberikan apersepsi yaitu mengajukan pertanyaan kepada siswa materi yang telah dipelajari yang berkaitan dengan materi yang akan dibahas, menyampaikan tujuan pembelajaran dan menginformasikan metode pembelajaran yang akan digunakan agar siswa mengetahui langkah yang akan dilakukan ketika proses pembelajaran berlangsung.

Setelah melakasanakan kegiatan awal, selanjutnya guru melakukan kegiatan inti. Kegiatan inti dimulai dengan menjelaskan materi secara singkat oleh guru dan memberikan kesempatan bertanya kepada siswa terhadap materi yang belum dipahami. Siswa mendengarkan semua penjelasan dari guru. Sebelum masuk ke dalam kelompok diskusi, guru membagikan LKS kapada masingmasing siswa kemudian siswa diminta bekerja sendiri selama beberapa menit kemudian siswa diminta berpasangan dengan teman sebangkunya mengerjakan LKS selama waktu yang telah ditentukan. Setelah berdiskusi dengan teman sebangku, siswa diminta berkumpul dengan berkelompoknya yang terdiri dari 4-5 siswa tiap kelompok dan membahas hasil kerjanya yang dipimpin oleh ketua kelompok. Masing-masing wakil dari anggota kelompok secara bergiliran mempresentasikan hasilnya di depan kelas, siswa yang lain memperhatikan dan memberi tanggapan. Langkah akhir dari pembelajaran yang dilakukan adalah guru bersama-sama dengan siswa menyimpulkan materi yang didiskusikan.

Pada saat proses kegiatan belajar mengajar berlangsung, reaksi siswa dari proses pembelajaran yang dilaksanakan adalah siswa cukup antusias dengan model pembelajaran yang diterapkan walaupun mereka masih kaku dalam berdiskusi dan mengeluarkan pendapat. Hal ini dapat dilihat ketika guru mensosialisasikan pembelajaran koperatif tipe berpikir berpasangan berbagi dan ketika proses diskusi berlangsung.

Dari hasil pengamatan yang dilakukan pada waktu pelaksanaan pembelajaran, didapatkan bahwa cara mengajar guru masih terlalu cepat sehingga siswa kurang memahami materi yang disampaikan oleh guru. Sebagian siswa belum dapat memanfaatkan kesempatan dalam berdiskusi dengan pasangannya, sehingga tugas kelompok dipercayakan pada anak yang paling pandai dalam kelompoknya, hanya agar tugas tersebut segera dapat diselesaikan tanpa mempertimbangkan setiap anggota kelompok belum memahami materi yang sedang dibahas. Disamping itu, kurangnya kemauan siswa dalam bertanya serta merespon pertanyaan dan siswa masih kesulitan dalam menyimpulkan materi yang dibahas.

Dari uraian di atas, maka pada siklus II guru harus memperbaiki cara menyampaikan materi sehingga siswa dapat mengerti terhadap materi yang disampaikan. Siswa juga diingatkan kembali tentang memanfaatkan kesempatan untuk berdiskusi dengan pasangannya dan cara kerja kelompok yang baik, dimana semua anggota harus lebih berperan aktif dalam diskusi kelompok berdasarkan hasil diskusi dengan pasangannya yang harus dikemukakan dalam diskusi kelompok.

Pada siklus II tahapan-tahapan yang akan dilaksanakan tidak jauh beda dari tahapan yang ada pada siklus I yaitu tahap perencanaan, pelaksanaan, observasi dan refleksi. Sebelum memulai proses kegiatan belajar mengajar guru telah membuat perencanaan yang meliputi Rencana Pelaksanaan Pembelajaran (RPP), lembar kerja siswa, soal evaluasi, kunci jawaban dan lembar observasi untuk siswa dan guru. Tidak jauh beda pada siklus I, pada siklus II kegiatan pembelajaran dilaksanakan sesuai dengan langkah-langkah yang tertuang dalam Rencana Pelaksanaan Pembelajaran (RPP) yang di mulai dari pendahuluan dengan memberikan apersepsi, menyampaikan tujuan pembelajaran. Kegiatan inti dengan menyampaikan materi secara singkat oleh guru dan siswa belajar sesuai dengan langkah-langkah pada model pembelajaran kooperatif tipe berpikir berpasangan berbagi. Langkah akhir dari pembelajaran yang dilakukan adalah guru bersama-sama dengan siswa menyimpulkan materi yang didiskusikan, merefleksikan.

Dalam tahap pelaksanaan proses belajar mengajar pada siklus II ini dilaksanakan untuk memperbaiki kekurangan-kekurangan atau kelemahan yang ada pada siklus I yaitu:

1. Cara mengajar guru masih terlalu cepat sehingga siswa kurang memahami materi yang disampaikan oleh guru. Hal ini ditindak lanjuti dengan guru harus memperbaiki cara menyampaikan materi sehingga siswa dapat mengerti terhadap materi yang disampaikan.

2. Sebagian siswa belum dapat memanfaatkan kesempatan dalam berdiskusi dengan pasangannya. Hal ini dapat ditindak lanjuti dengan pemberian motivasi oleh guru tentang pentingnya berdiskusi dengan pasangannya.

3. Sebagian siswa belum terbiasa bekerja kelompok, sehingga tugas kelompok dipercayakan pada anak yang paling pandai dalam kelompoknya, hanya agar tugas tersebut segera dapat diselesaikan tanpa mempertimbangkan setiap anggota kelompok yang belum memahami materi yang sedang dibahas. Hal ini ditindak lanjuti dengan cara guru mengingatkan kembali pada siswa tentang memanfaatkan kesempatan untuk berdiskusi dengan pasangannya dan cara kerja kelompok yang baik, dimana semua anggota harus lebih berperan aktif dalam diskusi kelompok berdasarkan hasil diskusi dengan pasangannya yang harus dikemukakan dalam diskusi kelompok.

4. Siswa masih kesulitan dalam menyimpulkan materi yang dibahas. Hal ini dapat ditindak 
lanjuti dengan membimbing siswa dalam menyimpulkan materi yang sudah dibahas.

Pada siklus II guru melakukan perbaikan terhadap kekurangan-kekurangan yang terdapat pada siklus I, yaitu sebagai berikut:

1. Jika pada siklus I, cara mengajar guru masih terlalu cepat sehingga siswa kurang memahami materi yang disampaikan oleh guru, pada siklus II, dalam menyampaikan materi sudah diperbaiki, dan sudah banyak melibatkan siswa.

2. Jika pada siklus I, sebagian siswa belum dapat memanfaatkan kesempatan dalam berdiskusi dengan pasangannya dan belum terbiasa bekerja kelompok, sehingga tugas kelompok dipercayakan pada anak yang paling pandai dalam kelompoknya, hanya agar tugas tersebut segera dapat diselesaikan tanpa mempertimbangkan setiap anggota kelompok yang belum memahami materi yang sedang dibahas. Pada siklus II, diskusi sudah kelihatan hidup karena guru sudah berhasil memotivasi siswa untuk aktif dalam diskusi baik dengan pasangannya maupun secara kelompok.

3. Jika pada siklus I, kemauan untuk bertanya dan merespon pertanyaan masih kurang. Pada siklus II, kemauan untuk bertanya dan maju ke depan kelas untuk menyelesaikan soal semakin meningkat walaupun hanya sebagian siswa. Hal ini pengaruh dari motivasi guru untuk membangkitkan kepercaan diri untuk bertanya dan merespon pertanyaan.

4. Jika pada siklus I, siswa masih kesulitan dalam menyimpulkan materi yang dibahas. Pada siklus II, siswa sudah mampu dalam menyimpulkan hasil diskusi walaupun intensitasnya masih kurang.

Beradasrkan analisis data pada siklus I menunjukkan bahwa aktivitas siswa tergolong cukup aktif dengan rata-rata skor aktivitas siswa sebesar 10,3. Aktivitas guru dengan rata-rata skor 2,14 dengan kategori baik. Rata-rata nilai hasil belajar siswa adalah 66 dengan ketuntasan klsikal mencapai $80 \%$. Pencapaian tersebut belum memenuhi standar ketuntasan minimal yang ditetapkan yaitu sebesar 85\%.

Pada siklus II, terdapat peningkatan aktivitas siswa yaitu pada siklus I rata-rata skor aktivitas siswa adalah 10,3 dengan kategori cukup aktif, pada siklus II terjadi peningkatan menjadi 14,11 dengan kategori sangat aktif. Aktivitas guru termasuk dalam kategori sangat baik dengan skor rata-rata 2,87. Nilai rata-rata hasil belajar siswa meningkat dari sebelumnya 66 menjadi 75 . Ketuntasan klasikal mencapai 90\% meningkat dari ketuntasan klasikal pada siklus I yang hanya mencapai $80 \%$. Dengan demikian pada siklus II ini menunjukkan bahwa hasil belajarnya sudah mencapai ketuntasan klasikal.

Hal ini menggambarkan bahwa siswa telah terbiasa dengan model pembelajaran kooperatif tipe berpikir berpasangan berbagi. Siswa sudah bisa memahami penjelasan materi dari guru. Siswa lebih terampil dalam menyelesaikan LKS secara individu dan kelompok. Sebagian besar siswa juga telah berperan aktif dalam kelompoknya, dapat bertukar informasi dengan anggota yang lain, dapat membantu anggota lain yang kesulitan dalam memahami materi. Siswa juga telah dapat bekerjasama dan melaksanakan evaluasi dengan baik.

Dari hasil penelitian di atas dapat dikatakan bahwa, penerapan model pembelajaran kooperatif tipe berpikir berpasangan berbagi dalam pembelajaran matematika dapat meningkatkan keaktifan siswa, hal tersebut didukung oleh adanya pemberian sikap kepada siswa yaitu guru berusaha untuk selalu menanamkan sikap kritis kepada siswa, sehingga terjadi komunikasi antara guru dan siswa.

Ketercapaian ketuntasan hasil belajar pada siklus II menunjukkan bahwa penerapan model pembelajaran kooperatif tipe berpikir berpasangan berbagi dapat meningkatkan ketuntasan hasil belajar siswa kelas VI tahun pelajaran 2014/2015 .

\section{SIMPULAN DAN SARAN}

\section{Simpulan}

Berdasarkan analisis data dan pembahasan dalam penelitian, maka dapat disimpulkan bahwa:

1. Penerapan model pembelajaran kooperatif tipe berpikir berpasangan berbagi dapat meningkatkan aktivitas belajar siswa. Antusiasme siswa dalam belajar juga meningkat sehingga pembelajaran menjadi lebih aktif, kreatif, efektif dan bermakna. Hal ini dapat dilihat dari rata-rata skor aktivitas siswa pada siklusi I adalah 10,3 dengan kategori cukup aktif meningkat menjadi 14,11 pada siklus II dengan kategori sangat aktif.

2. Penerapan model pembelajaran kooperatif tipe berpikir berpasangan berbagi dapat meningkatkan hasil belajar siswa kelas VI SDN Arjangka. Hal ini dapat dilihat dari rata-rata nilai evaluasi hasil belajar siswa siklus I yaitu 66 , ratarata nilai evaluasi hasil belajar siswa siklus II sebesar 75. Sedangkan prosentase ketuntasan klasikal pada siklus I yaitu $80 \%$, dan meningkat pada siklus II sebesar $90 \%$.

\section{Saran-saran}

1. Bagi peserta didik

Hendaknya menjadikan pembelajaran kooperatif tipe berpikir berpasangan berbagi menjadi sebuah inovasi belajar untuk memudahkan pembelajaran matematika yang dianggap sulit dan pelajaran matematika akan menjadi labih menarik dan mudah dimengerti.

2. Bagi pendidik

Guru hendaknya pandai-pandai dalam memilih metode dalam pembelajaran dan mensiasatinya sesuai dengan bidang yang diajarkan dan minat belajar siswa. Adanya model pembelajaran kooperatif tipe berpikir berpasangan berbagi menjadi salah satu metode dalam pembelajaran sehingga pembelajaran menjadi lebih aktif, kreatif, efektif, inovatif dan menyenangkan. 
90 Paedagoria, Vol. 8, No. 1, April 2017, hal. 81-90

\section{UCAPAN TERIMA KASIH}

Dengan penuh rasa hormat, saya ucapkan teimakasih kepada:

Kepala Dinas Pendidikan Kabupaten Lombok Tengah yang telah memfasilitasi, mengizinkan penulis untk mengadakan penelitian hingga dapat terlaksana dengan baik.

Bapak Pengurus PGRI Kec. Pringgarata dan Ketua Gugus yang telah menfasilitasi dalam seminar hasil penelitian Guru-guru Kecamatan Pringgarata.

Bapak Kepala sekolah yang selalu memberi dukungan sejak awal hingga terlaksananya penelitian ini dengan baik.

Rekan-rekan guru yang telah memberi dukungan baik secara moral maupun tindakan langsung dalam pelaksanaan penelitian ini.

\section{DAFTAR RUJUKAN}

[1] Arifin, Zaenal. 2009. Evaluasi Pembelajaran Prinsip-TeknikProsedur. Bandung

[2] Corebima, dkk. 2009. Penelitian Tindakan Kelas (Modul Diklat Sertifikasi Guru). Mataram: UNIVERSITAS MATARAM.

[3] Djamarah, Syaiful Bahri. 2002. Psikologi Belajar. Banjarmasin: PT RINEKA CIPTA.

[4] Hamalik, Oemar. 2001. Proses Belajar Mengajar. Bandung: PT Bumi Aksara.

[5] Hanafiah, Nanang, dkk. 2009. Konsep Strategi Pembelajaran. Bandung: PT Refika Aditama.

[6] Isjoni. 2010. Pembelajaran Kooperatif. Pekanbaru: CV ALFABETA.

[7] Lie, Anita. 2010. Cooperative Learning. Jakarta: PT Gramedia.

[8] Sudjana, Nana. 1987. Dasar-Dasar Proses Belajar Mengajar. Bandung: Sinar Baru Algensindo.

[9] Trianto. 2007. Model-model Pembelajaran Inovatif Berorientasi Konstruktivistik (Konsep, Landasan Teoritis Praktis dan Implementasinya. Surabaya: PRESTASI PUSTAKA. 